\title{
Breeding blueberries for a changing global environment: a review
}

\author{
Gustavo A. Lobos ${ }^{1,2 *}$ and James F. Hancock ${ }^{2}$ \\ ${ }^{1}$ Faculty of Agricultural Sciences, Plant Breeding and Phenomic Center, Universidad de Talca, Talca, Chile, ${ }^{2}$ Department of \\ Horticulture, Michigan State University, East Lansing, MI, USA
}

\section{OPEN ACCESS}

Edited by:

Edmundo Acevedo,

University of Chile, Chile

Reviewed by:

Margherita Irene Beruto, Istituto Regionale per la Floricoltura,

Italy

Carlos E. Muñoz Schick Universidad de Chile, Chile

*Correspondence:

Gustavo A. Lobos,

Facultad de Ciencias Agrarias, Universidad de Talca, 2 Norte 685,

Talca 3460000 , Chile globosp@utalca.cl; gustavol@msu.edu

Specialty section: This article was submitted to Crop Science and Horticulture,

a section of the journal

Frontiers in Plant Science

Received: 06 July 2015 Accepted: 10 September 2015 Published: 30 September 2015

Citation:

Lobos GA and Hancock JF (2015) Breeding blueberries for a changing global environment: a review. Front. Plant Sci. 6:782. doi: 10.3389/fp/s.2015.00782
Today, blueberries are recognized worldwide as one of the foremost health foods, becoming one of the crops with the highest productive and commercial projections. Over the last 100 years, the geographical area where highbush blueberries are grown has extended dramatically into hotter and drier environments. The expansion of highbush blueberry growing into warmer regions will be challenged in the future by increases in average global temperature and extreme fluctuations in temperature and rainfall patterns. Considerable genetic variability exists within the blueberry gene pool that breeders can use to meet these challenges, but traditional selection techniques can be slow and inefficient and the precise adaptations of genotypes often remain hidden. Marker assisted breeding (MAB) and phenomics could aid greatly in identifying those individuals carrying adventitious traits, increasing selection efficiency and shortening the rate of cultivar release. While phenomics have begun to be used in the breeding of grain crops in the last 10 years, their use in fruit breeding programs it is almost non-existent.

Keywords: Vaccinium, drought, heat, UV, phenotype, highbush, MAB, phenomics

\section{Introduction}

Over the last 100 years, the geographical area where highbush blueberries are grown has expanded dramatically (Retamales and Hancock, 2012). The northern highbush blueberry (NHB) is native to the eastern and mid-western portions of the USA, where winters are very cold, summers are moderate and chilling hours are high (Table 1). The Industry was first established in New Jersey (1910), but within a few decades had expanded to North Carolina (1920), Michigan (1930), and the Pacific Northwest (1940). From there it leapfrogged to Europe (1970s), New Zealand/Australia (1980s), central Chile (1980s), and most recently China (2000s).

The expansions into the Pacific Northwest, Mexico, and Chile were into climates with much less severe winters, while the introductions into China were into much colder regions. Cultivars developed in Michigan and New Jersey have generally thrived in the milder climates of the Pacific Northwest, but many of them suffer from the high irradiance in Chile and the cold of China.

Southern highbush blueberry (SHB) types were originally developed in the 1980 s by incorporating genes from native species from the southern US to reduce the chilling requirement of NHB. SHB were first established in Florida and Georgia (1980s) and then moved to north central Chile (1980), Argentina and Spain (1990), California (2000) and most recently Mexico, Peru and Ecuador (2010s).

The introductions of SHB into California, north Central Chile, and Spain were into hotter and dryer climates than those in Florida and Georgia (Table 1), and in southern Chile with much higher UV levels (Huovinen et al., 2006). The expansions into Mexico and Ecuador were from low to 


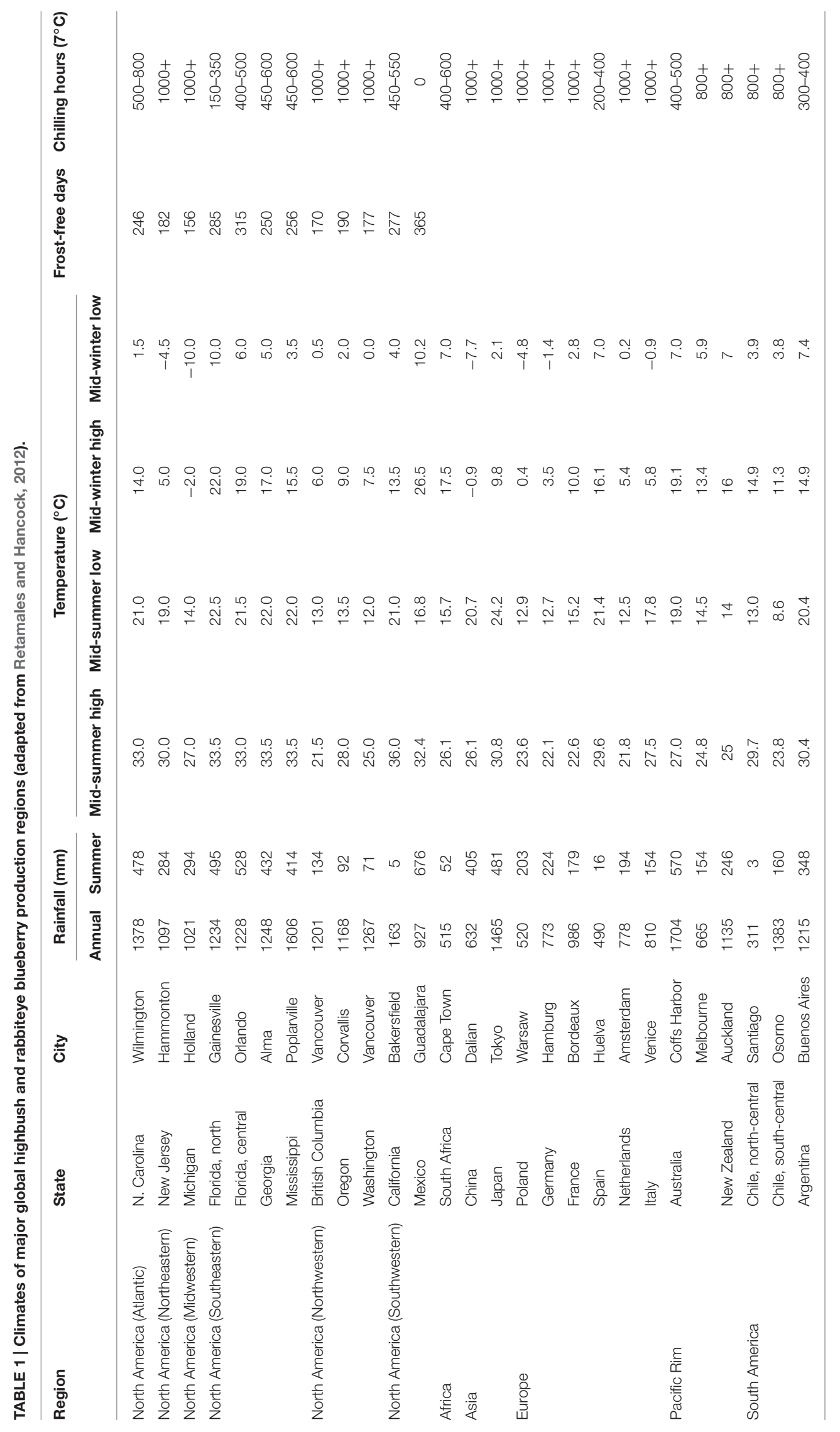


moderate chill conditions to regions with few to no hours under $7^{\circ} \mathrm{C}$. In general, the cultivars that have done well in Florida and Georgia have also performed well in the hotter, drier production regions of California, central Chile, and Spain. However, only a few low chill cultivars have performed well in Mexico and Peru, and many of them suffer under the high UV levels of Chile.

During the last couple of decades, a constant stream of successful cultivars has been released from a number of breeding programs. These programs have focused on releasing cultivars with reduced chilling hours in warmer regions, increased cold hardiness in colder regions, and higher performance under high $\mathrm{pH}$, temperature and radiative stress, but there is still much room for improvement. To achieve these goals, blueberry breeders have incorporated genes from many species within the Vaccinium genus through inter-specific hybridization (Table 2), which should prove to be a rich genetic pool for further improvements.

In this paper, we review the environmental challenges facing blueberry cultivation due to global warming. We describe the state of the art of blueberry breeding and outline how future varietal development can be enhanced by marker assisted breeding (MAB) and phenomics.

\section{Environmental Challenges to Blueberry Cultivation}

The expansion of highbush blueberry growing into colder and warmer regions will be challenged by the alterations in global temperature and rainfall patterns, both associated with increases in atmospheric $\mathrm{CO}_{2}$ concentrations. From the "Industrial Revolution" carbon dioxide has increased in a significant way and will continue to do so. It is estimated that under the most conservative scenario, atmospheric $\mathrm{CO}_{2}$ concentrations at the end of the century will be at least double to the preindustrial era, increasing by 35\% from year 2005 (IPCC, 2007b). As atmospheric concentrations of greenhouse gases rise due to the human activity, worldwide climatic patterns are being greatly altered (United Nations, 2010). The Intergovernmental Panel on Climate Change (IPCC), reports that during the past 150 years, global mean temperatures raised $0.045^{\circ} \mathrm{C}$ per decade, but in the last 25 years have increased almost four times $\left(0.177^{\circ} \mathrm{C}\right)$ (IPCC, 2007a). Two separate analyses done recently by NASA (National Aeronautics and Space Administration) and NOAA (National Oceanic and Atmospheric Administration) have concluded that 2014 was the warmest year since 1880 (NASA, 2015). It is

TABLE 2 | Genetic composition of some of the cultivated blueberries.

\begin{tabular}{|c|c|c|c|c|c|c|c|c|}
\hline \multirow[t]{2}{*}{ Cultivar } & \multicolumn{8}{|c|}{ Specie composition (\%) } \\
\hline & VC & VA & VD & Va & VT & Vc & VE & Others \\
\hline Elliott, Brigitta, Liberty, Aurora, Lateblue, Jersey & 100.0 & & & & & & & \\
\hline Duke & 96.0 & 4.0 & & & & & & \\
\hline Bluecrop & 93.6 & 6.4 & & & & & & \\
\hline Hannah's Choice & 92.2 & 7.8 & & & & & & \\
\hline Avonblue & 86.7 & 0.8 & 5.0 & 7.5 & & & & \\
\hline Lenoir & 85.2 & 2.3 & 12.5 & & & & & \\
\hline Draper & 84.5 & 6.0 & 1.6 & 1.2 & 0.4 & & & 6.3 \\
\hline O’Neal & 84.0 & 10.0 & 3.0 & 3.0 & & & & \\
\hline Misty & 81.0 & 1.0 & 9.0 & 6.0 & 3.0 & & & \\
\hline Ozarkblue & 77.3 & 3.9 & 11.3 & 7.5 & & & & \\
\hline Summit & 77.3 & 3.9 & 11.3 & 7.5 & & & & \\
\hline Reveille & 77.2 & 4.1 & 3.1 & 2.3 & 0.8 & & & 12.5 \\
\hline Sampson & 76.6 & 10.9 & 12.5 & & & & & \\
\hline Magnolia & 75.5 & 5.7 & 10.0 & 7.5 & 1.3 & & & \\
\hline Legacy & 73.4 & 1.6 & 25.0 & & & & & \\
\hline Star & 71.9 & 7.7 & 7.2 & 5.9 & 1.0 & & & 6.3 \\
\hline Camellia & 71.8 & 1.6 & 19.7 & 3.8 & & & & 3.1 \\
\hline Bluetta, Patriot, Sunrise & 72.0 & 28.0 & & & & & & \\
\hline Carteret & 71.5 & 3.5 & & & & & 25.0 & \\
\hline Millennia & 66.5 & 5.3 & 1.3 & 1.9 & & & & 25.0 \\
\hline Jubilee & 56.6 & 2.7 & 26.9 & 7.5 & & & & 6.3 \\
\hline Emerald & 54.4 & 1.9 & 13.9 & 1.5 & 0.2 & & & 28.1 \\
\hline Sierra & 50.0 & 2.0 & 20.0 & 15.0 & & 13.0 & & \\
\hline Cara's Choice & 47.7 & 2.3 & 20.0 & 15.0 & & 15.0 & & \\
\hline Sharpblue & 43.7 & 28.8 & 15.0 & & & & & 12.5 \\
\hline Biloxi & 41.8 & 1.8 & 32.5 & 11.3 & & & & 12.6 \\
\hline
\end{tabular}

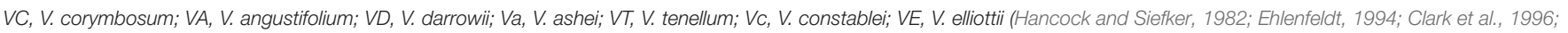
Hancock et al., 1997; Brevis et al., 2008; Lee et al., 2012; Rowland et al., 2013). 
expected that during the next century global temperatures will be increased by an additional $1.1-6.4^{\circ} \mathrm{C}$ (Jin et al., 2011).

The increases in temperature are associated with extreme variations in weather patterns, resulting in severe droughts, unusually heavy rains and atypically hot temperatures (Allen and Ingram, 2002). Since the 1970s, the frequency of warm nights and days is increasing dramatically (IPCC, 2007a). For example, in the main blueberry production area in Chile (approximately between 35 and $38^{\circ}$ Latitude S), precipitation diminished around $25 \%$ during the 20th Century, and it is estimated that there will be a further reduction of 5-15\% over the next 30 years (Meza et al., 2003; Santibañez and Santibañez, 2007, 2008; United Nations, 2010). These dramatic changes led Friend (2010) to suggest that "Quantifying and explaining the current global distribution of plant production, and predicting its future responses to climate change and increasing atmospheric $\mathrm{CO}_{2}$, are therefore major scientific objectives." High temperatures and drought can significantly reduce the productivity and the quality of the harvested organ (Moretti et al., 2010), restricting the areas (latitudes and soils) where economically important species can be grown.

The activity and development of humanity has not only increased atmospheric $\mathrm{CO}_{2}$ levels but also levels of chlorofluorocarbons from aerosols, refrigerators, and other equipment that conditions the air. These compounds destroy the ozone layer, which selectively absorbs ultraviolet light. Ozone absorbs $100 \%$ of UV-C, prevents the passage of UV-B (near 90\%) but does not affect the UV-A transmission (de Gruijl and van der Leun, 2000). In the southern $\left(35-60^{\circ}\right)$ and northern $\left(35-60^{\circ}\right)$ hemisphere, the annual mean ozone quantities during 2006-2009 were lower than between 1964 and 1980 (6 and 3.5\%, respectively) (WMO, 2011).

The average UV erythemal irradiance, which indicates potential biological damage to human skin from solar ultraviolet radiation, has steadily risen as the amount of ozone has decreased (WMO, 2011). Compared with the 1970s, surface erythemal UV radiation has increased $7 \%$ in winter-spring and $4 \%$ in summer-fall in the northern hemisphere mid-latitudes, $6 \%$ yearround in the mid-southern hemisphere latitudes, and $22 \%$ in the Antarctic and Arctic in the spring (Madronich et al., 1998). In the summertime, erythemal UV irradiance in the southern hemisphere is up to $40 \%$ higher than values in the northern hemisphere (Madronich et al., 1998). If the Montreal Protocol is followed, it is possible that UV values will return to 1980 levels by the middle of this century, but this is dependent on multifaceted global cooperation (Kazantzidis et al., 2010; McKenzie et al., 2011).

\section{Implications of Climate Change on Blueberry Breeding}

The aspect of global warming that most needs attention from blueberry breeders is the dramatic seasonal fluctuations now occurring in rainfall and temperature patterns. Cultivars well adapted to "average conditions," often do not have sufficient plasticity to perform well under the range of conditions now being faced. For example, an unusually warm spring in Michigan in 2012 lead to very early floral development, and as a result, when temperatures returned to normal later in the spring, a high percentage of flowers were damaged by frost. An unusually hot summer in the Pacific Northwest in 2012, resulted in the fruit of most cultivars being too soft for extended storage. This was followed by an unusually cold winter in 2013-2014, where high percentages of the floral buds were heavily damaged. In Chile, falls and winters are becoming progressively milder in many areas, causing some cultivars to bloom out of season (O'Neal, Snowchaser and Misty, among others).

To maintain and extend the geographic range where blueberries are grown, breeders will need to be much more cognizant of the potential range of environments that the cultivars will face. They will need to take care not to release cultivars that are narrowly adapted to average conditions. Among the environmental challenges faced by blueberry breeders are:

\section{Winter Cold}

The range of the highbush blueberry has been limited by extreme winter cold. Cold hardiness is a complex interaction between rate of acclimation (development of freezing tolerance) and deacclimation (loss of developed freezing tolerance), as well as degree of mid-winter tolerance. This is extremely important since unseasonably warm midwinter spells can trigger a premature deacclimation, exposing the bush to freeze damage (Arora and Rowland, 2011).

In general, northern highbush cultivars survive much colder mid-winter temperatures than southern highbush ones, although considerable variability exists within groups and among Vaccinium species (Hancock et al., 1997; Ehlenfeldt et al., 2003, 2006, 2007; Dhanaraj et al., 2004; Rowland et al., 2004; Ehlenfeldt and Rowland, 2006; Hanson et al., 2007). In full dormancy, northern highbush genotypes have been found to range in tolerance from -20 to $-30^{\circ} \mathrm{C}$. Few southern highbush have been evaluated, although "Legacy" tolerates temperatures to $-17^{\circ} \mathrm{C}$ and "Ozarkblue" to $-26^{\circ} \mathrm{C}$. US 245 , an inter-species hybrid of US 75 ("Bluecrop" $\times$ V. darrowii "Fla 4B") $\times$ "Bluecrop," is tolerant to at least $-24^{\circ} \mathrm{C}$.

To date, the primary approach to developing more cold tolerant blueberries has been to hybridize lowbush with highbush to produce "half-high" types (Trehane, 2004; Hancock et al., 2008a). However, the shorter stature of the half-highs and the fact they become covered and protected with snow may be the primary basis of their increased tolerance (El-Shiekh et al., 1996). Due to the lack of formal comparisons of flower bud tolerance to winter cold in highbush, lowbush and half-highs, it is unknown how much more cold tolerant highbush can be made through introgression. It would be productive to determine if several other wild species carry useful genes for cold hardiness including V. boreale, V. constablaei, and V. myrtilloides (Galletta and Ballington, 1996; Ehlenfeldt and Rowland, 2006). Ehlenfeldt et al. (2007) showed that when $V$. ashei was hybridized with $V$. constablaei, cold hardiness was positively associated with the percentage of $V$. constablaei genes.

Little formal genetic analysis of cold tolerance of tetraploid blueberry has been performed. Arora et al. (2000) found 
in diploid populations that the cold hardiness data fit a simple additive-dominance model of gene action, with the additive effects being greater than the dominance ones. During cold acclimation, specific genes are expressed in floral buds that increase cold tolerance (Naik et al., 2007). Arora et al. (1997a), working with "Bluecrop," “Tifblue," and "Gulfcoast," found a close relationship between floral bud dehydrin concentration and the level of cold hardiness. Similar results were found by Rowland et al. (2004) and Dhanaraj et al. (2005). This suggests that dehydrin concentration might be a way to predict the cold hardiness of selections in a breeding program.

It is important to note that studies of cold hardiness under field or artificial conditions can lead to different conclusions. When "Bluecrop" (NHB) and "Tifblue" (Rabbiteye blueberry$\mathrm{RE}$ ) flower buds were assessed in the field, $\mathrm{LT}_{50}$ (maximum level of cold-hardiness) were close to -27 and $-25^{\circ} \mathrm{C}$ (respectively), whereas the same cultivars in cold room conditions $\left(4^{\circ} \mathrm{C}\right)$ reached maximums around -24 and $-17^{\circ} \mathrm{C}$, respectively (Arora et al., 1997b; Arora and Rowland, 2011). There were almost twice as many "Bluecrop" genes expressed in the cold room than in the field, suggesting that many of the genes induced in the cold room were responding to low temperature (specifically $4^{\circ} \mathrm{C}$ ) and were not contributing to freezing tolerance per se. In contrast, more "Tifblue" genes were expressed in the field than under the controlled conditions. This suggests that there is a strong genotype $\times$ environment interaction associated with cold tolerance and any screen designed to select cold hardy genotypes, must be conducted under field conditions or under realistic controlled protocols (Arora and Rowland, 2011).

It may be possible to determine when a plant is approaching full dormancy by measuring the expression of the $\beta$-amylase gene. Lee et al. (2012) showed in the NHB "Jersey" and the SHB "Sharpblue" that there was an abrupt reduction in starch in shoots in the middle of cold acclimation, which was associated with an increase in the expression of the $\beta$-amylase gene. This change was positively correlated with the total amount of soluble solids in the wood, which likely served as osmoprotectants able to reduce the freezing point. Inter-species differences in the level of expression of $\beta$-amylase genes in northern and southern highbush were described by Rowland et al. (2008).

\section{Spring and Fall Frost}

Freezing damage to developing flowers in the spring is a major problem in most blueberry production regions, with both $\mathrm{NHB}$ and SHB. It is a rare year when at least a fraction of the flower buds is not damaged. Rate of deaclimation likely plays a role in early spring flower bud tolerance. Ehlenfeldt (2003) found the northern highbush "Duke" deacclimated the fastest in a mixed group of 12 cultivars, while the southern highbush "Magnolia," the northern highbush $\times$ rabbiteye pentaploid hybrid "Pearl River," the rabbiteye $\times V$. constablaei "Little Giant" and the half-highs "Northcountry" and "Northsky" were the slowest. Northern highbush "Bluecrop" and "Weymouth," southern highbush "Legacy" and "Ozarkblue" were intermediate. While there is evidence of considerable variability, no formal genetic studies have been done on deaclimation rates.
Identifying late bloom or slower deacclimating genotypes will be useful for breeding spring-frost tolerant cultivars (Rowland et al., 2005). Because of the chances of frosts and the direct relation between the stage of floral development and the relative bud hardiness, those cultivars with late bloom dates tend to suffer less frost damage than those flowering earlier (Spiers, 1976; Hancock et al., 1987; Patten et al., 1991; Lin and Pliszka, 2003). When Hancock et al. (1987) assessed flower bud injury in 18 highbush blueberry cultivars after two spring frosts in Michigan, they found significant differences in proportion of brown ovaries among cultivars, ranging from 25 to $94 \%$. Most of the variation was associated with stage of bud development.

Bloom date is strongly correlated with ripening date, but early ripening cultivars have been developed that have later than average flowering dates such as the NHB "Duke," "Huron" and "Spartan," and the SHB "Santa Fe" and "Star." Bloom date, ripening interval and harvest dates are highly heritable in blueberry populations (Lyrene, 1985; Hancock et al., 1991) with strong genotype by environmental interactions (Finn et al., 2003). Finn and Luby (1986) found additive genetic variation was more important than non-additive effects for date of $50 \%$ bloom, 50\% ripe fruit and for length of fruit development interval in populations from hybrids between $V$. angustifolium and $V$. corymbosum. Where spring frosts are a problem, breeders can focus on developing cultivars with late bloom dates and where earliness is premium, selection will need to be made on ripening interval as well.

Flower buds also can be damaged by rapid freezes in the fall. The flower buds of SHB cultivars are generally considered to acclimate more slowly in the fall than those of NHB ones, and as a result are more subject to late fall freezes; however, few formal screens of germplasm have been conducted on this characteristic (Rowland et al., 2005, 2013; Hanson et al., 2007). Leaf retention in the fall does not appear to be a good predictor of rate of DA, as Hanson et al. (2007) found that "Ozarkblue" and US 245 retain their leaves until the very late fall, but they are just as hardy as the mid-season standard "Bluecrop." Bittenbender and Howell (1975) also found no correlation between flower bud hardiness and fall leaf retention.

There are not many studies that have evaluated the effect of the spring frost on open flowers, and most of them have been done on RE (Spiers, 1976; Gupton, 1983; NeSmith et al., 1999). Among RE cultivars, "Southland" proved to be more frost-tolerant than "Delite," "Woodard," "Climax," and "Tifblue" (Gupton, 1983). Nevertheless, interspecific crosses with RE would not be recommended to increase bud tolerance to frost since, at similar stages of floral bud development, RE tend to be more sensitive than NHB and SHB (Patten et al., 1991). Rowland et al. (2013), studying the sensitiveness of five northern highbush blueberries cultivars ("Bluecrop," "Elliott," "Hannah's Choice," "Murphy," and "Weymouth") to frost damage of open flowers, concluded that "Hannah's Choice" and "Murphy" were the most tolerant whereas "Bluecrop" was the most susceptible. Among the cultivars analyzed by Rowland et al. (2013), female parts from "Elliott" (styles), "Hannah's Choice" (styles and exterior ovaries) and "Murphy" (styles) were more frost-tolerant than those structures of "Bluecrop," and the male organs from 
"Murphy" (filaments and anthers) were more frost-tolerant than "Bluecrop." These differences need to be studied in other cultivars and exploited for breeding.

\section{Chilling Requirement}

Expanding the range of adaptation of the NHB by reducing its chilling requirement has been a major breeding goal over the last 50 years (Hancock et al., 2008a). This was largely accomplished by incorporating genes from the southern diploid species $V$. darrowii into $V$. corymbosum via unreduced gametes, although hybridizations with native southern $V$. corymbosum and $V$. ashei also played a role. Cultivars with an almost a continuous range of chilling requirements (hours below $7^{\circ} \mathrm{C}$ ) are now available from 0 to $1000 \mathrm{~h}$.

Most SHB are grown in areas with 250-600 chilling hours each winter. SHB cultivars vary widely in their performance without any chilling hours. Surprisingly, one of the best adapted cultivars to this system is "Biloxi," which requires 500 chilling hours $\left(<7^{\circ} \mathrm{C}\right)$ in Mississippi, where it was developed. The response to chilling is clearly a complex interaction and many factors play a role including sensitivity to temperature shifts, floral development time, response to photoperiodic change and temperature thresholds.

The genetics of the chilling requirement has not been formally determined, although segregation patterns suggest that it is largely quantitatively inherited with the low chilling requirement showing some dominance. The precise temperature necessary to break dormancy has not been determined, but Mainland et al. (1977) and Spiers (1976) have proposed that the chilling requirement of highbush blueberries is at least partially satisfied by temperatures below 1.4 and above $12.4^{\circ} \mathrm{C}$. It is possible that blueberry genotypes vary in the threshold temperatures that are required to break dormancy, although this has not been documented. Southern highbush cultivars with complex ancestry may be particularly variable in their temperature thresholds.

\section{Heat and Drought Tolerance}

When heat stress is present in blueberries, the quick response needed to supply the atmospheric demand, puts the plant and its fruit at permanent threat (Chen et al., 2012). High summer temperatures, such as in the subtropical southeast China or the dry Mediterranean north of Chile, impact on the productivity of highbush blueberries across much of their range (Darnell, 2000; Chen et al., 2012). It is thought that SHB are more tolerant of high temperatures than $\mathrm{NHB}$, but both types commonly experience summer temperatures in the field that have negative impacts on $\mathrm{CO}_{2}$ assimilation rates and fruit quality. In general, optimal temperatures have been shown to vary between 20 and $25^{\circ} \mathrm{C}$ (Davies and Flore, 1986).

No formal studies have been conducted on the genetics of photosynthetic heat tolerance in blueberry, but genetic variation has been documented. Moon et al. (1987b) evaluated the optimum temperature for photosynthesis in different highbush cultivars, determining ranges of $18-6^{\circ} \mathrm{C}$ for Jersey and $14-22^{\circ} \mathrm{C}$ for Bluecrop. A temperature of $30^{\circ} \mathrm{C}$ has been shown to reduce photosynthesis in NHB cultivars by $22-51 \%$ (Hancock et al., 1992); the authors reported that "Jersey," "Elliott," and "Rubel" showed a decrease in photosynthesis between 22 and 27\% whereas for "Spartan," "Bluejay," and "Patriot" it was between 41 and 51\%. Trehane (2004) describes "Ozarkblue" and "Jubilee" as varieties that perform well in hot summers. Chen et al. (2012) found that at high temperatures, up to $40-45^{\circ} \mathrm{C}$, a number of photosynthetic parameters were damaged in "Brigitta," but they stayed largely intact in "Sharpblue," and "Duke"; "Misty" performed in the middle. In this study, at high temperatures, there were increases in hydrogen peroxide, super oxide radical and $\mathrm{F}_{0}$ (minimum fluorescence in the dark-adapted state), while Fv/Fm (maximum photochemical quantum yield of photosystem II) and ÔPS II (quantum efficiency of PSII photochemistry) decreased.

Southern highbush cultivars may have obtained higher photosynthetic heat tolerance from Vaccinium darrowii (Lyrene, 2002). Moon et al. (1987a) found that $\mathrm{CO}_{2}$ assimilation $(A)$ in Fla $4 \mathrm{~B}$ of $V$. darrowii was similar at 20 and $30^{\circ} \mathrm{C}$, while $A$ in the pure northern highbush "Bluecrop" dropped by almost $30 \%$ across this same range. Transpiration rates were also much lower in Fla 4B than "Bluecrop." This difference was found to be heritable, with a tetraploid $\mathrm{F}_{1}$ hybrid actually having higher $A$ than the two parents (Moon et al., 1987b; Hancock et al., 1992). The selection, Fla $4 \mathrm{~B}$ has been used to generate many of the important southern highbush cultivars including "Biloxi," "Emerald," "Legacy," and "Star" (Lyrene and Sherman, 2000; Draper and Hancock, 2003). There may also be additional sources of heat tolerance in the native southern species $V$. tenellum, $V$. myrsinites, $V$. pallidum, $V$. ashei, V. elliottii, V. stamineum, Vaccinium arboreum, southern diploids and tetraploids of V. corymbosum (Luby et al., 1991).

It would seem likely that the photosynthetic heat tolerance of both $\mathrm{NHB}$ and $\mathrm{SHB}$ types can be increased by crossing the most heat tolerant genotypes, since there is considerable genetic variability for this trait both within and among blueberry species.

High temperatures also negatively impact fruit quality and storage life of highbush blueberries. Temperatures higher than $32^{\circ} \mathrm{C}$ during the maturation of the fruit can give rise to smaller, soft fruits and with waxes that have greater susceptibility of being lost by means of the rubbing (by leaves or during the harvest) (Mainland, 1989).

Blueberries have a relatively inefficient water conducting systems, characterized by the lack of root hairs (Gough, 1994). Root anatomy and architecture should be a key trait, but unfortunately it is almost unexplored, e.g., $V$. arboreum is drought tolerant specie because it has deep tap roots in contrast to the spreading, shallow root systems of highbush blueberry. Hence, drought tolerance of highbush blueberries might also be enhanced by using species material in breeding.

In his screens of wild species material, Erb et al. (1988a,b) found $V$. elliottii, $V$. darrowii, and $V$. ashei to be the most drought tolerant species and this characteristic was transmitted to hybrid progeny. Moon et al. (1987a) found transpiration rates and leaf conductance $(g s)$ to water vapor to be much lower in $V$. darrowii than "Bluecrop" at high temperature. This suggests that $V$. darrowii may have higher drought tolerance through decreased stomatal opening and subsequent restriction of water loss. 
Other sources of drought tolerance likely include the native species Vaccinium stamineum and V. arboretum (Hancock et al., 2008a). V. stamineum is the most drought tolerant species in the southeastern U.S.A., but hybrids derived with species in section Cyanococcus have not been vigorous (Ballington, 1980; Lyrene, 2006). The use of $V$. arboreum appears to be more promising, as this species can be crossed with $V$. darrowii to produce vigorous hybrids, and these hybrids can be used as a bridge to tetraploid SHB types (Lyrene, 1991; Brooks and Lyrene, 1998; Olmstead et al., 2013).

In response to water deficit, plants stop shoot growth affecting their final height and diameter (Mingeau et al., 2001). Bluecrop is one of the cultivars which has been studied most, proving to be highly sensitive to water deficit, showing a rapid stomatal closure, and reduced gas exchange (Cameron et al., 1989; Rho et al., 2012), berry size and yields (Améglio et al., 2000). When "Bluecrop" was subjected to severe hydric restriction, a reduction in the yield (31-49\%) was observed (Perrier et al., 2000). Similar results were found for other highbush cultivars like Rancocas (Lee et al., 2006) and Jersey (Cameron et al., 1989). Rho et al. (2012) also found that along with the reduction in gas exchange found in "Bluecrop" under water deficit $(-1.9 \mathrm{MPa})$, an increment in the electron transport rate (ETR) occurs, indicating photorespiration is also affected.

When Estrada et al. (2015) studied how SHB, RE, and NHB responded to drought conditions, with or without heat stress, they found that under each stress SHB and RE had a better photoprotection capacity, while the NHB showed increments in its photochemical capacity. When both stresses were present, just NHB "Liberty" and "Elliott" had increased $\mathrm{ETR}_{\max }$ (maximum electron transport rate), the coefficient of photochemical fluorescence quenching ( $\mathrm{qP}$ and $\mathrm{qL}$ ) and the effective photochemical quantum yield of photosystem II [Y(II)]. This suggests these two cultivars should be considered as parents if reduction of photo-oxidative damage is required. This tool could be used to screen genotypes much faster than other classic measurements, such as gas exchange rate, chlorophyll content, stem water potential, etc., making the monitoring of stressed plants more efficient (Ralph and Gademann, 2005; Estrada et al., 2015).

The priority of this trait for the breeder varies depending on location and irrigation availability. It should be mentioned that currently most blueberries are cultivated under irrigation or with irrigation supplementation.

\section{High UV Light}

Ozone depletion itself, is not a major contributor to global warming, but increases in UV irradiance have large, direct impacts on plant productivity (Boesgaard et al., 2012). In some latitudes, plants will not only have to deal with extreme photosynthetic active radiation and heat, but also with high UV radiation. Is not unusual to observe damaged plants in commercial fields (Yáñez et al., 2009), as well as among breeding families, in central Chile with reddened and curled leaves and what appear to be localized burns on fruit. Shading nets have been shown to enhance productivity of blueberries in central Chile, but the direct influence of UV light has not be investigated (Retamales et al., 2008; Lobos et al., 2009, 2012, 2013, 2015).

Kakani et al. (2003), reviewing 129 studies of the effect of UVB on 35 crops, reported that higher levels of UV-B (most affected by the ozone depletion) were associated with vegetative and reproductive morphology alterations, decreases in chlorophyll content and photosynthesis, and chlorotic or necrotic patches on leaves or fruit. Little formal work has been done on the effect of UV light on northern highbush blueberries, and most of what has been done has focused on postharvest improvement through short treatments of UV-B on harvested fruit (Perkins-Veazie et al., 2008; Eichholz et al., 2011).

The damaging effects of high UV light have been documented in other Vaccinium species. Albert et al. (2008) and Boesgaard et al. (2012) found a reduction of net photosynthesis in $V$. uliginosum throughout the season and damage to photosystem II (PS II) through the diminution of the fluorescence measured as Fv/Fm. Kossuth and Biggs (1978) tested the effects of 15, 24, and 44 units of UV-B on the rabbiteye blueberry "Woodard" and found that the higher doses reduced fruit growth and surface bloom, and under high doses of UV-B the fruit skin actually appeared burned.

Among the mechanisms that might be selected to improve UV tolerance in blueberries is the ability of the leaf surface to reflect part of the incident radiation (Semerdjieva et al., 2003a,b). The thickness of the epidermis of the leaf and the concentration of absorbent compounds could also be improved to counteract the damaging effects of UV radiation (Batschauer, 1998; Boesgaard et al., 2012). Increases in levels of phenols (flavonoids and hidroxamic acid), could also help counter the degradative effects of high UV-B on DNA (Rozema et al., 1997; Ruhland et al., 2005). Defense responses to UV-B have not been evaluated in highbush blueberry; however, Semerdjieva et al. (2003a,b) noted in three other species (V. myrtillus L., V. vitis-idaea L., and V. uliginosum L.) in the north of Sweden, that there were noticeable differences in quantity of phenolic compounds. In all species, high UV-B led to an increase in phenolic compounds, but some genotypes responded more than others, and the plants with the highest flavonoid content had the least UV-B damage.

\section{New Frontiers for the Breeding of Blueberries}

The breeding of highbush blueberries can be a long and tedious process. Traditional approaches take from 10 to 20 years from the original cross to cultivar release and often the precise adaptive range of a cultivar is not known until farmers have grown it for a number of years. Two relatively new techniques called "MAB" and "Phenomics" could greatly facilitate blueberry breeding. $\mathrm{MAB}$ would aid in the selection of those individuals most likely to carry adventitious traits and Phenomics would allow for much more easy, fast and precise characterization of the superior types. It is possible that individuals could be selected for their adaptability to variable environmental conditions with MAB even though they were not exposed to those conditions in the field. 


\section{Marker Assisted Breeding (MAB)}

All breeding programs revolve around identifying the optimal traits for a cultivar. Most blueberry breeding programs utilize traditional approaches to identify desirable types, such as walking along rows of crosses in the field or doing simple laboratory assays on fruit quality and disease resistance. However, in many other crops, MAB is used to facilitate and speed up the release of new cultivars (Cabrera-Bosquet et al., 2012; Araus and Cairns, 2014).

MAB is based on DNA diagnostic tests that can identify potential parents and progeny carrying desirable traits. This process allows selection to be moved all the way back to conception in the breeder's minds, helping them to only make crosses that create desirable trait combinations in offspring, increasing the efficiency of the entire process. It also permits selection to be moved from the field to the greenhouse, so that only seedlings predicted to be superior are planted in the field for further evaluation. In addition, MAB allows for the assessment of traits that are difficult to predict in the field such as chilling hour requirement or heat tolerance.

To use MAB to broaden the environmental range where highbush blueberries can be grown, it will be necessary to find genetic variability associated with expanded adaptations. The rich germplasm diversity currently being used by blueberry breeders (Table 2) is likely to contain useful genes. The major stumbling block to using MAB will be the collection of precise data on the adaptations of potential breeding parents. Evaluations of genotypes in the field will require that the extreme conditions occur when the plants are in the field (Arora and Rowland, 2011). Care will need to be taken to evaluate genotypes in appropriate environments and in many cases controlled experiments will need to be undertaken. Most likely a genotype will need to be evaluated in multiple environments to obtain an accurate representation of its adaptations. This will often be tedious and time consuming, but once markers are found that are tightly linked to the genes regulating adaptations of interest, future screening will be greatly facilitated through MAB. As we discuss below, field screening could be greatly streamlined using phenomic techniques involving spectrometry and thermography.

The first genetic maps of blueberries are beginning to emerge that will set the groundwork for MAB. Rowland's group at the USDA-ARS (Genetics of Fruit and Vegetable Improvement Laboratory, Beltsville, MD, USA) developed the first blueberry map using a diploid population segregating for chilling requirement (Rowland and Levi, 1994). Their population was a cross between an inter-specific hybrid ( $V$. darrowii $\times V$. corymbosum) and another clone of $V$. corymbosum. They have continued to periodically add markers to this map and at last report had 265 markers mapped to 12 linkage groups. They have used this map to identify quantitative trait loci for cold tolerance and chilling requirement (Rowland et al., 2014). Allan Brown (North Carolina State University, NC, USA) and Eric Jackson (General Mills, Crop Bioscience, MN, USA) have led teams that sequenced the genome of a $V$. darrowii $\times V$. corymbosum hybrid and used this information to generate a more dense chromosome map with 1200 markers.
A major research initiative has been undertaken by Lisa J. Rowland, Nahla Bassil (USDA-ARS, National Clonal Repository, Corvallis, OR, USA), Julie Graham and Susan McCallum (The James Hutton Institute, Dundee, UK) and Jim Olmstead (University of Florida, Gainesville, FL, USA) to develop a linkage map of the tetraploid cross "Jewel" (SHB) x "Draper" (NHB) (Rowland et al., 2012). Replicated progeny of that cross were planted at five locations across the USA and data was collected on a wide array of traits including fruit quality, developmental rates, chilling hour requirements and growth patterns. A QTL analysis is currently being conducted to search for markers for these traits.

The first few thousand expressed sequence tags (ESTs) have been generated and made publicly available for the Ericaceae family, about 5000 from blueberry and about 1200 from rhododendron (Rowland et al., 2010, 2014; Die and Rowland, 2013) (http://bioinformatics.towson.edu/BBGD/). These ESTs from blueberry and rhododendron were generated as parts of projects focused on cold acclimation research, and the ESTs are from non-acclimated and cold acclimated flower bud libraries, in the case of blueberry (Dhanaraj et al., 2004, 2007), and from non-acclimated and cold acclimated leaf libraries, in the case of rhododendron (Wei et al., 2005). Another 16,000 ESTs have been generated from blueberry fruit by the New Zealand Institute for Plant and Food Research Ltd. (formerly HortResearch), but they are not publicly available.

\section{Phenomics}

The success of breeding programs is reflected in the number of individuals released at the end of the selection process (Hancock et al., 2008b). In order to be successful, breeders must generate thousands of hybrids annually and evaluate them for a number of years. What ultimately is selected is dependent on local environmental conditions (Araus and Cairns, 2014).

Because of the large number of genotypes that need to be evaluated, deep phenotypic characterizations of the material often becomes impractical due to the time and costs involved (White et al., 2012; Kipp et al., 2014). For this reason, conventional breeding generally focuses on different visual characteristics (e.g., fruit color, cluster tightness, disease resistance, growth habit, flowering, and ripeness dates) and a few that require measurements of average complexity (e.g., yield, soluble solids, firmness).

To effectively develop cultivars well adapted to fluctuations in environmental stresses, blueberry breeders will have to evaluate a number of morpho-physiological and physico-chemical traits that they are not used to considering (Figure 1). The only reasonable way to fulfill all these needs is through acquisition of high-dimensional phenotypic data (high-throughput field phenotyping) or "Phenomics" (Houle et al., 2010). Nowadays, there are a number of remote sensing devices, techniques and analysis, mostly non-destructive, which have proven very helpful in the characterization of the phenotype (Furbank and Tester, 2011; White et al., 2012; Araus and Cairns, 2014).

Among the remote sensing technologies with the greatest potential for use in phenomics are spectrometry and thermography. Spectroradiometers are widely used to measure plant reflectance $(\mathrm{R})$, whose spectral signature (graphic 


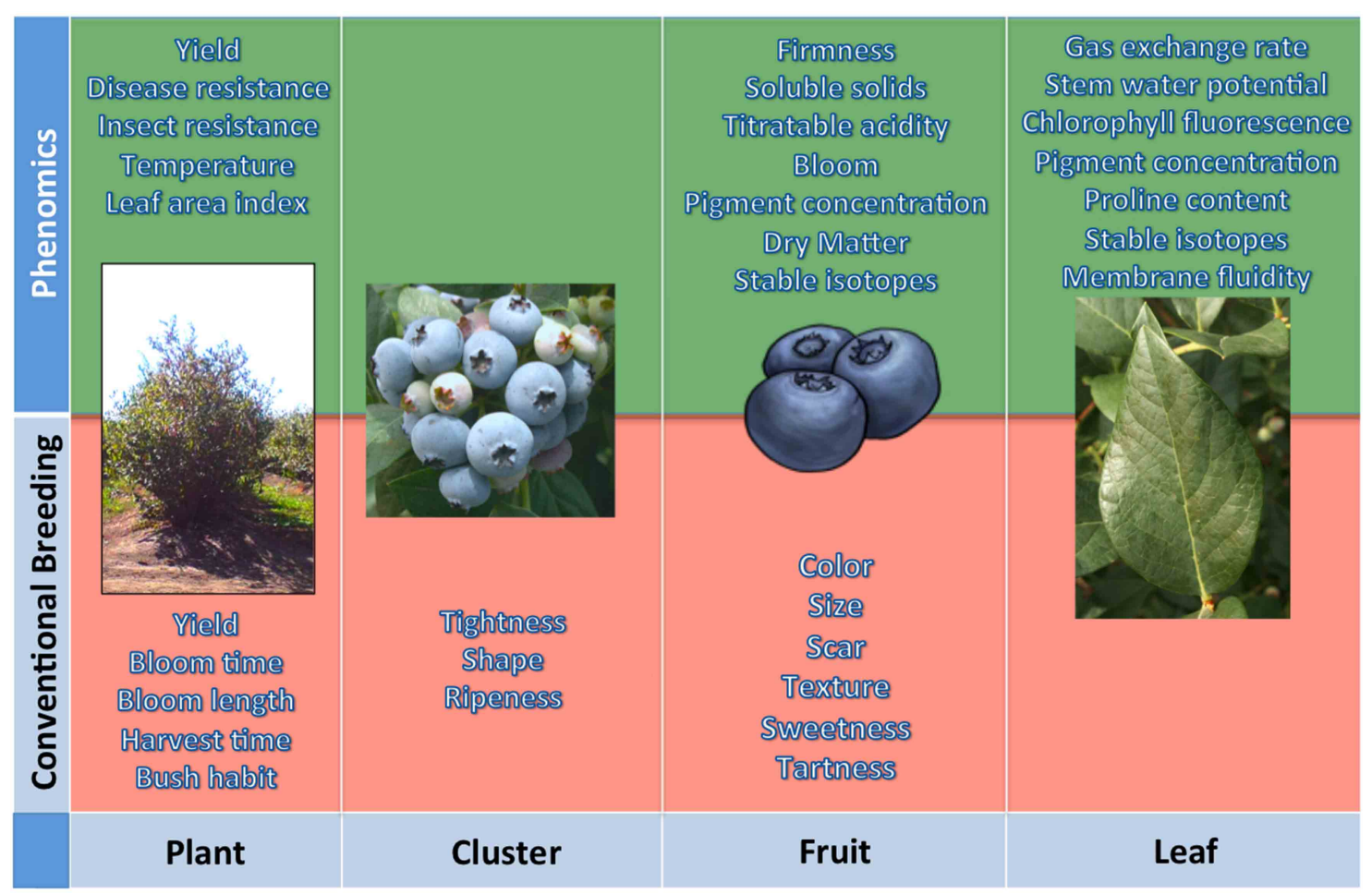

FIGURE 1 | The traits commonly evaluated by a plant breeder are highlighted in red. Others that can be estimated by phenomics are highlighted in green-mostly of these are valuable morpho-physiological and physico-chemical traits that most breeders are not able to consider.

characterization of reflected segment of wavelengths) is closely associated with the absorption at certain wavelengths that are linked to specific characters or plant conditions (Araus and Cairns, 2014). Thermography uses plant temperature as an efficient tool for the study of the spatial and temporal heterogeneity of plant water status and how it responds to the environment.

While these techniques are not new, their use was expanded tremendously during mid 1980s and is now being widely used in plant ecophysiology and postharvest studies (estimation of yield, nutritional content in leaves, gas exchange rate, fruit quality, biotic and abiotic stress, etc.) (Garriga et al., 2014; Lobos et al., 2014). Measurements that before usually took months, weeks, or days can now be accomplished in hours or even minutes for a large number of genotypes (Figure 2).

In spectrometry, reflectance data is used to generate "Spectral Reflectance indices" (SRI). Initially SRIs were simple relationships between wavelengths or spectral bands. The first SRI was the "Simple Ratio," calculated as the ratio of the near infrared (NIR) to the visible (VIS) (SR $=\mathrm{R}_{\mathrm{NIR}} / \mathrm{R}_{\mathrm{VIS}}$ ), and the "Normalized Difference Vegetation Index" $\left[\mathrm{NDVI}=\left(\mathrm{R}_{\mathrm{NIR}}{ }^{-}\right.\right.$ $\left.\left.\mathrm{R}_{\mathrm{VIS}}\right) /\left(\mathrm{R}_{\mathrm{NIR}}+\mathrm{R}_{\mathrm{VIS}}\right)\right]$. Since then, and incorporating specific wavelengths, SRIs have been used in different species to estimate green biomass and leaf area index (Tucker and Sellers, 1986), plant water status (Peñuelas et al., 1993), radiation use efficiency (Peñuelas et al., 1995), water content in leaves (Sims and Gamon, 2003), photosynthetic capacity and efficiency (Inoue et al., 2008), micro and macro nutrients in leaves (Basayigit and Senol, 2009), yield and carbon isotope discrimination (Lobos et al., 2014) among many others.

Since the 1960s, plant temperature has been widely used as an indicator of water status (Tanner, 1963). Initially, temperature measurements were performed by thermocouples in contact with the leaves. Later, the development of infrared sensors allowed faster measurements of leaves or canopies. With thermal imaging it is possible to detect biotic or abiotic pre-symptomatic responses, providing a powerful tool to evaluate a high number of samples in only a few minutes (Costa et al., 2013; Araus and Cairns, 2014). The development of cheaper devices has made this approach available to farmers and breeders. Thermometry analysis has been fine-tuned over time and the different parts of the image (soil, air, leaves, stems, branches, etc.) can now be isolated, allowing for the evaluation of specific tissues, organs or individuals (Costa et al., 2013; Araus and Cairns, 2014).

To date, spectrometry and thermography have been used to only a limited extent on blueberries. There are a few studies where the antioxidant content in NHB was evaluated using spectrometry (total phenols, total flavonoids, total anthocyanins, and ascorbic acid) (Sinelli et al., 2008; Bai et al., 2014). The ideal "Brigitta" harvest date was determined in the field using reflectance data (Beghi et al., 2009), and a blueberry ripeness index (BRI) has been developed (Beghi et al., 2013). Guidetti et al. (2009) used a portable spectroradiometer Vis-NIR to accurately estimate soluble solids, firmness and functional compounds 

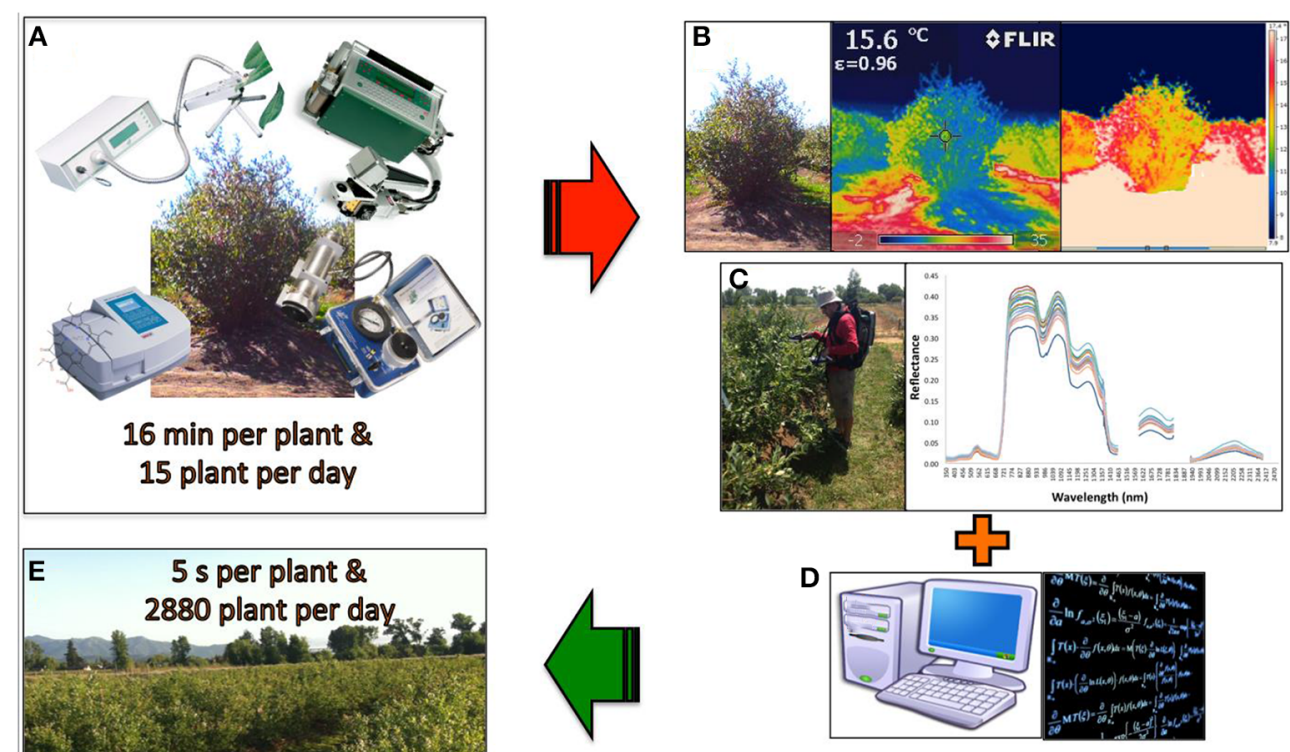

FIGURE 2 | When drought or heat stress needs to be assessed, the evaluation window per day is reduced to $\mathbf{4} \mathbf{h}$. A basic physiological plant evaluation (gas exchange rate, stem water potential, chlorophyll fluorescence, and pigment concentration) (A) takes about 16 min per plant, representing a characterization of a maximum 15 genotypes per day. When thermography (B) and spectrometry (C) is considered, linear and non-linear modeling (D) can streamline the evaluation of plant status, further increasing the number of genotypes that can be evaluated in a breeding population per day (E).

(anthocyanins, flavonoids, polyphenols, and ascorbic acid) in fresh and homogenized fruit samples of "Brigitta" and "Duke." Other work on blueberries focused on monitoring osmo and air dehydration processes (Sinelli et al., 2011), SHB cultivar identification (Yang and Lee, 2011; Yang et al., 2012), and the recognition of foreign materials (leaves and stems) among frozen blueberries (Tsuta et al., 2006; Sugiyama et al., 2010). In the wild lowbush blueberry ( $V$. angustifolium) reflectance data has also been used for detection of internal larvae fruit infestation (Peshlov et al., 2009), in situ levels of foliar nitrogen (Bourguignon, 2006; Maqbool et al., 2012) and to evaluate vegetative (leaf area index) and reproductive (flower number, fruit set, and berry yield) parameters (Percival et al., 2012). Most recently, hyperspectral imaging has been used to predict soluble solids content and firmness in NHB fruit (Leiva-Valenzuela et al., 2013, 2014), to identify damaged fruit (Leiva-Valenzuela et al., 2012; Leiva-Valenzuela and Aguilera, 2013), to classify blueberry fruit growth stages (Yang et al., 2012, 2014), and as a tool for early detection of leaf rust in blueberries (Ahlawat et al., 2011). Escobar-Opazo (2015) found that in blueberry some of the physiological parameters were significantly correlated with reflectance data (e.g., ETR $\mathrm{max}_{\max }$ and chlorophyll a/b > 0.90; $A$ and $g s>0.65)$.

During the last decade, spectrometry and thermography have begun to be used in the breeding of grain crops, but their use in fruit breeding programs is almost non-existent. Even in the grain crops, their use has been limited to the evaluation of small numbers of genotypes, in general $<20$. SRI will need to be replaced by more complex bio-mathematical models, to fully provide breeders with the solid and reliable information they need for plant selection. When this happens, the efficiency of selection should dramatically improve, and well adapted genotypes will be released at a faster rate. The future challenge will be to develop techniques that can screen a large number of genotypes simultaneously (hundreds or thousands) (Figure 2).

\section{Concluding Remarks and Future Perspectives}

Considerable genetic variability exists in the highbush blueberry germplasm base that can be used by breeders to meet the environmental challenges associated with climate change. There has already been extensive range expansion of blueberries into hotter and drier environments. There is no reason to believe that there is not additional genetic variability that can be deployed to further enhance cold acclimation, heat, high UV, and drought tolerance of blueberries. Perhaps the greatest challenge associated with climate change and blueberry range expansion will be the development of blueberry cultivars that can resist extremes in environmental variability. Ongoing research to develop DNA diagnostic markers for key physiological tolerances will aid greatly in the breeding of these stress resistant types. To generate robust markers for $\mathrm{MAB}$, it will be necessary to have precise phenotypic characterizations, making phenomics a powerful tool that could aid greatly in identifying the superior types.

\section{Acknowledgments}

This work was supported by the National Commission for Scientific and Technological Research CONICYT Chile 
(FONDEF IDEA 14I10106 and FONDEQUIP EQM130073), and the research programs "Adaptation of Agriculture to Climate
Change (A2C2)" and "Nucelo Científico Multidisciplinario" from Universidad de Talca, Chile.

\section{References}

Ahlawat, V., Jhorar, O., Kumar, L., and Backhouse, D. (2011). “Using hyperspectral remote sensing as a tool for early detection of leaf rust in blueberries," in34th International Symposium on Remote Sensing of Environment - The GEOSS Era: Towards Operational Environmental Monitoring (Sydney).

Albert, K. R., Mikkelsen, T. N., and Ro-Poulsen, H. (2008). Ambient UV$\mathrm{B}$ radiation decreases photosynthesis in high arctic Vaccinium uliginosum. Physiol. Plant 133, 199-210. doi: 10.1111/j.1399-3054.2008.01065.x

Allen, M. R., and Ingram, W. J. (2002). Constraints on future changes in climate and the hydrologic cycle. Nature 419, 224-232. doi: 10.1038/nature01092

Améglio, T., Roux, X. L., Mingeau, M., and Perrier, C. (2000). Water relations of highbush blueberry under drought conditions. Acta Hortic. 537, 273-278. doi: 10.17660/actahortic.2000.537.30

Araus, J. L., and Cairns, J. E. (2014). Field high-throughput phenotyping: the new crop breeding frontier. Trends Plant Sci. 19, 52-61. doi: 10.1016/j.tplants.2013.09.008

Arora, R., and Rowland, L. J. (2011). Physiological research on winter-hardiness: deacclimation resistance, reacclimation ability, photoprotection strategies, and a cold acclimation protocol design. HortScience 46, 1070-1078.

Arora, R., Rowland, L. J., and Panta, G. R. (1997a). Chill-responsive dehydrins in blueberry: are they associated with cold hardiness or dormancy transitions? Physiol. Plant. 101, 8-16. doi: 10.1111/j.1399-3054.1997.tb01813.x

Arora, R., Rowland, L. J., Lehman, J. S., Lim, C. C., Panta, G. R., and Vorsa, N. (2000). Genetic analysis of freezing tolerance in blueberry (Vaccinium section Cyanococcus). Theor. Appl. Genet. 100, 690-696. doi: 10.1007/s0012200 51341

Arora, R., Wisniewski, M. E., and Rowland, L. J. (1997b). Low temperatureinduced expression of dehydrins in deciduous fruit crops and their relation to cold acclimation and/or dormancy. Acta Hortic. 441, 175-182. doi: 10.17660/actahortic.1997.441.23

Bai, W., Yoshimura, N., and Takayanagi, M. (2014). Quantitative analysis of ingredients of blueberry fruits by near infrared spectroscopy. J. Near Infrared Spectrosc. 22, 357-365. doi: 10.1255/jnirs.1129

Ballington, J. R. (1980). Crossability between subgenus Cyanococcus (Gray) Klotzsch and subgenus Polycodium (Raf.) Sleumer in Vaccinium. HortScience 15,419 .

Basayigit, L., and Senol, H. (2009). Prediction of plant nutrient contents in deciduous orchards fruits using spectroradiometer. Int. J. ChemTech. Res. 1, 212-224.

Batschauer, A. (1998). Photoreceptors in higher plants. Planta 206, 479-492. doi: $10.1007 / \mathrm{s} 004250050425$

Beghi, R., Giovenzana, V., Spinardi, A., Guidetti, R., Bodria, L., and Oberti, R. (2013). Derivation of a blueberry ripeness index with a view to a lowcost, handheld optical sensing device for supporting harvest decisions. Trans. ASABE 56, 1551-1559. doi: 10.13031/trans.56.10169

Beghi, R., Guidetti, R., Oberti, R., and Bodria, L. (2009). "Feasibility of a simplified handheld optical system for blueberries ripeness field evaluation," in 5th International Technical Symposium on Food Processing, Monitoring Technology in Bioprocesses and Food Quality Management, eds M. Zude and O. Schlüter (Potsdam).

Bittenbender, H., and Howell, G. (1975). Interactions of temperature and moisture content on spring de-acclimation of flower buds of highbush blueberry. Can. J. Plant Sci. 55, 447-452. doi: 10.4141/cjps75-070

Boesgaard, K. S., Albert, K. R., Ro-Poulsen, H., Michelsen, A., Mikkelsen, T. N., and Schmidt, N. M. (2012). Long-term structural canopy changes sustain net photosynthesis per ground area in high arctic Vaccinium uliginosum exposed to changes in near-ambient UV-B levels. Physiol. Plant. 145, 540-550. doi: 10.1111/j.1399-3054.2011.01564.x

Bourguignon, C. (2006). The Feasibility of Determining Foliar Nitrogen, Phosphorus and Potassium Contents using Existing Hyperspectral Technologies in Wild Blueberry. Halifax, NS: Dalhousie University.
Brevis, P. A., Bassil, N. V., Ballington, J. R., and Hancock, J. F. (2008). Impact of wide hybridization on highbush blueberry breeding. J. Am. Soc. Hortic. Sci. 133, 427-437.

Brooks, S. J., and Lyrene, P. M. (1998). Level of self- and cross-fertility of derivatives of Vaccinium arboreum x Vaccinium section Cyanococcus hybrids. HortScience 33, 1066-1068.

Cabrera-Bosquet, L., Crossa, J., von Zitzewitz, J., Serret, M. D., and Luis Araus, J. (2012). High-throughput Phenotyping and genomic selection: the frontiers of crop breeding converge. J. Integr. Plant Biol. 54, 312-320. doi: 10.1111/j.17447909.2012.01116.x

Cameron, J. S., Brun, C. A., and Hartley, C. A. (1989). The influence of soil moisture stress on the growth and gas exchange characteristics of young highbush blueberry plants (Vaccinium corymbosum L.). Acta Hortic. 241, 254-259. doi: 10.17660/actahortic. 1989.241.41

Chen, W., Cen, W., Chen, L., Di, L., Li, Y., and Guo, W. (2012). Differential sensitivity of four highbush blueberry (Vaccinium corymbosum L.) cultivars to heat stress. Pak. J. Bot. 44, 853-860.

Clark, J. R., Moore, J. N., and Draper, A. D. (1996). 'Ozarkblue' southern highbush blueberry. HortScience 31, 1043-1045.

Costa, J. M., Grant, O. M., and Chaves, M. M. (2013). Thermography to explore plant-environment interactions. J. Exp. Bot. 64, 3937-3949. doi: $10.1093 / \mathrm{jxb} / \mathrm{ert029}$

Darnell, R. L. (2000). "Blueberries," in Temperate Fruit Crops in Warm Climates, ed A. Erez (Dordrecht; London: Kluwer Academic Publishers), 429-444.

Davies, F. S., and Flore, J. A. (1986). Gas exchange and flooding stress of highbush and rabbiteye blueberry. J. Am. Soc. Hortic. Sci. 111, 565-571.

de Gruijl, F. R., and van der Leun, J. (2000). Environmental and health: 3. Ozone depletion and ultraviolet radiation. Can. Med. Assoc. J. 163, 851-855.

Dhanaraj, A. L., Alkharouf, N. W., Beard, H. S., Chouikha, I. B., Matthews, B. F., Wei, H., et al. (2007). Major differences observed in transcript profiles of blueberry during cold acclimation under field and cold room conditions. Planta 225, 735-751. doi: 10.1007/s00425-006-0382-1

Dhanaraj, A. L., Slovin, J. P., and Rowland, L. J. (2004). Analysis of gene expression associated with cold acclimation in blueberry floral buds using expressed sequence tags. Plant Sci. 166, 863-872. doi: 10.1016/j.plantsci.2003.11.013

Dhanaraj, A. L., Slovin, J. P., and Rowland, L. J. (2005). Isolation of a cDNA clone and characterization of expression of the highly abundant, cold acclimationassociated $14 \mathrm{kDa}$ dehydrin of blueberry. Plant Sci. 168, 949-957. doi: 10.1016/j.plantsci.2004.11.007

Die, J. V., and Rowland, L. J. (2013). Advent of genomics in blueberry. Mol. Breed. 32, 493-504. doi: 10.1007/s11032-013-9893-1

Draper, A., and Hancock, J. (2003). Florida 4B: native blueberry with exceptional breeding value. J. Am. Pomol. Soc. 57, 138-141.

Ehlenfeldt, M. K. (1994). The genetic composition and tetrasomic inbreeding coefficients of highbush blueberry cultivars. HortScience 29, 1342-1345.

Ehlenfeldt, M. K. (2003). Investigations of metaxenia in northern highbush blueberry (Vaccinium corymbosum L.) cultivars. J. Am. Pomol. Soc. 57, 26-31.

Ehlenfeldt, M. K., and Rowland, L. J. (2006). Cold-hardiness of Vaccinium ashei and $\mathrm{V}$. constablaei germplasm and the potential for northern-adapted rabbiteye cultivars. Acta Hortic. 715, 77-80. doi: 10.17660/actahortic.2006.715.8

Ehlenfeldt, M. K., Ogden, E. L., Rowland, L. J., and Vinyard, B. (2006) Evaluation of midwinter cold hardiness among 25 rabbiteye blueberry cultivars. HortScience 41, 579-581.

Ehlenfeldt, M. K., Rowland, L. J., and Arora, R. (2003). Bud hardiness and deacclimation in blueberry cultivars with varying species ancestry: Flowering time may not be a good indicator of deacclimation. Acta Hortic. 626, 39-44. doi: 10.17660/actahortic.2003.626.4

Ehlenfeldt, M. K., Rowland, L. J., Ogden, E. L., and Vinyard, B. T. (2007). Floral bud cold hardiness of Vaccinium ashei, V. constablaei, and hybrid derivatives and the potential for producing northern-adapted rabbiteye cultivars. HortScience $42,1131-1134$ 
Eichholz, I., Huyskens-Keil, S., Keller, A., Ulrich, D., Kroh, L. W., and Rohn, S. (2011). UV-B-induced changes of volatile metabolites and phenolic compounds in blueberries (Vaccinium corymbosum L.). Food Chem. 126, 60-64. doi: 10.1016/j.foodchem.2010.10.071

El-Shiekh, A., Wildung, D. K., Luby, J. J., Sargent, K. L., and Read, P. E. (1996). Long-term effects of propagation by tissue culture or softwood single-node cuttings on growth habit, yield, and berry weight of 'Northblue' blueberry. J. Am. Soc. Hortic. Sci. 121, 339-342.

Erb, W. A., Draper, A. D., and Swartz, H. J. (1988a). Methods of screening blueberry populations for drought resistance. HortScience 25, 312-314.

Erb, W. A., Draper, A. D., and Swartz, H. J. (1988b). Screening interspecific blueberry seedling populations for drought resistance. J. Am. Soc. Hortic. Sci. $113,599-604$.

Escobar-Opazo, A. (2015). Spectroradiometry Estimation Models for Blueberries Genotype selection under Drought Conditions, with or without Heat Stress. Master thesis. Universidad de Talca, Talca.

Estrada, F., Escobar, A., Romero-Bravo, S., González-Talice, J., Poblete-Echeverría, C., Caligari, P. D. S., et al. (2015). Fluorescence phenotyping in blueberry breeding for genotype selection under drought conditions, with or without heat stress. Sci. Hortic. 181, 147-161. doi: 10.1016/j.scienta.2014.11.004

Finn, C. E., Hancock, J. F., Mackey, T., and Serçe, S. (2003). Genotype x environment interactions in highbush blueberry (Vaccinium sp. L.) families grown in Michigan and Oregon. J. Am. Soc. Hortic. Sci. 128, 196-200.

Finn, C., and Luby, J. J. (1986). Inheritance of fruit development interval and fruit size in blueberry progenies. J. Am. Soc. Hortic. Sci. 111, 784-788.

Friend, A. D. (2010). Terrestrial plant production and climate change. J. Exp. Bot. 61, 1293-1309. doi: 10.1093/jxb/erq019

Furbank, R. T., and Tester, M. (2011). Phenomics - technologies to relieve the phenotyping bottleneck. Trends Plant Sci. 16, 635-644. doi: 10.1016/j.tplants.2011.09.005

Galletta, G. J., and Ballington, J. R. (1996). "Blueberries, cranberries and lingonberries," in Fruit Breeding, Vine and Small Fruit Crops, Vol. 2, eds J. Janick and J. N. Moore (New York, NY: John Wiley and Sons, Inc), 1-107.

Garriga, M., Retamales, J. B., Romero-Bravo, S., Caligari, P. D. S., and Lobos, G. A. (2014). Chlorophyll, anthocyanin and gas exchangechanges assessed by spectroradiometry in Fragaria chiloensis under salt stress. J. Integr. Plant Biol. 56, 505-515. doi: 10.1111/jipb.12193

Gough, R. E. (1994). The Highbush Blueberry and its Management. Binghamton, NY: Food Product Press an Imprint of the Haworth Press, Inc.

Guidetti, R., Berghi, R., Bodria, L., Spinardi, A., Mignani, I., and Folini, L. (2009). Prediction of blueberry (Vaccinium corymbosum) ripeness by a portable Vis-NIR device. Acta Hortic. 810, 877-885. doi: 10.17660/actahortic.2009. 810.117

Gupton, C. L. (1983). Variability among rabbiteye blueberry cultivars for tolerance of flowers to frost. HortScience 18, 713-714.

Hancock, J. F., and Siefker, J. H. (1982). Levels of inbreeding in highbush blueberry cultivars. HortScience 17, 363-366.

Hancock, J. F., Erb, W. A., Goulart, B. L., and Scheerens, J. C. (1997). Blueberry hybrids with complex genetic backgrounds evaluated on mineral soils: cold hardiness as influenced by parental species and location. Acta Hortic. 446, 389-396. doi: 10.17660/actahortic.1997.446.57

Hancock, J. F., Haghighi, K., Krebs, S. L., Flore, J. A., and Draper, A. D. (1992). Photosynthetic heat stability in highbush blueberries and the possibility of genetic improvement. HortScience 27, 1111-1112.

Hancock, J. F., Lyrene, P., Finn, C. E., N., V., and Lobos, G. A. (2008a). “Blueberry and cranberry," in Temperate Fruit Crop Breeding: Germplasm to Genomics, ed J. F. Hancock (Dordrecht: Kluwer Academic Publishers), 115-149.

Hancock, J. F., Sjulin, T. M., and Lobos, G. A. (2008b). “Strawberries," in Temperate Fruit Crop Breeding: Germplasm to Genomics ed J. F. Hancock (Dordrecht: Kluwer Academic Publishers), 393-437.

Hancock, J., Nelson, J., Bittenbender, H., Callow, P., Cameron, J., Krebs, S., et al. (1987). Variation among highbush blueberry cultivars in susceptibility to spring frost. J. Am. Soc. Hortic. Sci. 112, 702-706.

Hancock, J., Sakin, M., and Callow, P. (1991). Heritability of flowering and harvest dates in Vaccinium corymbosum. Fruit Varieties J. 45, 173-176.

Hanson, E. J., Berkheimer, S. F., and Hancock, J. F. (2007). Seasonal changes in the cold hardiness of the flower buds of highbush blueberry with varying species ancestry. J. Am. Pomol. Soc. 61, 14-18.
Houle, D., Govindaraju, D. R., and Omholt, S. (2010). Phenomics: the next challenge. Nat. Rev. Genet. 11, 855-866. doi: 10.1038/nrg2897

Huovinen, P., Gómez, I., and Lovengreen, C. (2006). A five-year study of solar ultraviolet radiation in southern Chile (39 degrees S): potential impact on physiology of coastal marine algae? Photochem. Photobiol. 82, 515-522. doi: 10.1562/2005-07-05-RA-601

Inoue, Y., Peñuelas, J., Miyata, A., and Mano, M. (2008). Normalized difference spectral indices for estimating photosynthetic efficiency and capacity at a canopy scale derived from hyperspectral and $\mathrm{CO} 2$ flux measurements in rice. Remote Sens. Environ. 112, 156-172. doi: 10.1016/j.rse.2007.04.011

IPCC. (2007a). "Climate change 2007: impacts, adaptation and vulnerability," in Contribution of Working Group II to the 4th Assessment Report of the Intergovernmental Panel on Climate Change (Cambridge, UK).

IPCC. (2007b). "Climate Change 2007: The Physical Basis," in Contribution of Working Group I to the 4th Assessment of the Intergovernmental Panel on Climate Change (Cambridge, UK).

Jin, B., Wang, L., Wang, J., Jiang, K. Z., Wang, Y., Jiang, X. X., et al. (2011). The effect of experimental warming on leaf functional traits, leaf structure and leaf biochemistry in Arabidopsis thaliana. BMC Plant Biol. 11:35. doi: 10.1186/1471-2229-11-35

Kakani, V. G., Reddy, K. R., Zhao, D., and Sailaja, K. (2003). Field crop responses to ultraviolet-B radiation: a review. Agric. For. Meteorol. 120, 191-218. doi: 10.1016/j.agrformet.2003.08.015

Kazantzidis, A., Tourpali, K., and Bais, A. F. (2010). Variability of cloud-free ultraviolet dose rates on global scale due to modeled scenarios of future ozone recovery. Photochem. Photobiol. 86, 117-122. doi: 10.1111/j.17511097.2009.00645.x

Kipp, S., Mistele, B., Baresel, P., and Schmidhalter, U. (2014). High-throughput phenotyping early plant vigour of winter wheat. Eur. J. Agron. 52, Part B, 271-278. doi: 10.1016/j.eja.2013.08.009

Kossuth, S. V., and Biggs, R. H. (1978). "Sunburned blueberries," in Proceedings of the Florida State Horticultural Society (Gainesville, FL).

Lee, H. J., Kim, S. J., Yu, D. J., Lee, B. Y., and Kim, T. C. (2006). Changes of photosynthetic characteristics in water-stressed 'Rancocas' blueberry leaves. Acta Hortic. 715, 111-117. doi: 10.17660/actahortic.2006.715.15

Lee, J. H., Yu, D. J., Kim, S. J., Choi, D., and Lee, H. J. (2012). Intraspecies differences in cold hardiness, carbohydrate content and $\beta$-amylase gene expression of Vaccinium corymbosum during cold acclimation and deacclimation. Tree Physiol. 32, 1533-1540. doi: 10.1093/treephys/tps102

Leiva-Valenzuela, G. A., and Aguilera, J. M. (2013). Automatic detection of orientation and diseases in blueberries using image analysis to improve their postharvest storage quality. Food Control 33, 166-173. doi: 10.1016/j.foodcont.2013.02.025

Leiva-Valenzuela, G. A., Lu, R., and Aguilera, J. M. (2012). "Assessment of internal quality of blueberry using hyperspectral imaging," in American Society of Agricultural and Biological Engineers Annual International Meeting (Dallas, TX), 2333-2347.

Leiva-Valenzuela, G. A., Lu, R., and Aguilera, J. M. (2013). Prediction of firmness and soluble solids content of blueberries using hyperspectral reflectance imaging. J. Food Eng. 115, 91-98. doi: 10.1016/j.jfoodeng.2012.10.001

Leiva-Valenzuela, G. A., Lu, R., and Aguilera, J. M. (2014). Assessment of internal quality of blueberries using hyperspectral transmittance and reflectance images with whole spectra or selected wavelengths. Innov. Food Sci. Emerg. Technol. 24, 2-13. doi: 10.1016/j.ifset.2014.02.006

Lin, W., and Pliszka, K. (2003). Comparison of spring frost tolerance among different highbush blueberry (Vaccinium corymbosum L.) cultivars. Acta Hortic. 626, 337-341. doi: 10.17660/actahortic.2003.626.45

Lobos, G. A., Acevedo-Opazo, C., Guajardo-Moreno, A., Valdés-Gómez, H., Taylor, J., and Laurie, V. F. (2015). Effects of kaolin-based particle film and fruit zone netting on Cabernet Sauvignon physiology and fruit quality. J. Int. Sci. Vigne Vin 49, 137-144.

Lobos, G. A., Matus, I., Rodriguez, A., Romero-Bravo, S., Araus, J. L., and del Pozo, A. (2014). Wheat genotypic variability in grain yield and carbon isotope discrimination under Mediterranean conditions assessed by spectral reflectance. J. Integr. Plant Biol. 56, 470-479. doi: 10.1111/jipb.12114

Lobos, G. A., Retamales, J. B., Del Pozo, A., Hancock, J. F., and Flore, J. A. (2009). Physiological response of Vaccinium corymbosum 'Elliott' to shading nets in Michigan. Acta Hortic. 810, 465-470. doi: 10.17660/actahortic.2009.810.60 
Lobos, G. A., Retamales, J. B., Hancock, J. F., Flore, J. A., Cobo, N. G., and del Pozo, A. (2012). Spectral irradiance, gas exchange characteristics and leaf traits of Vaccinium corymbosum L. 'elliott' grown under photo-selective nets. Environ. Exp. Bot. 75, 142-149. doi: 10.1016/j.envexpbot.2011.09.006

Lobos, G. A., Retamales, J. B., Hancock, J. F., Flore, J. A., Romero-Bravo, S., and del Pozo, A. (2013). Productivity and fruit quality of Vaccinium corymbosum cv. Elliott under photo-selective shading nets. Sci. Hortic. 153, 143-149. doi: 10.1016/j.scienta.2013.02.012

Luby, J. J., Ballington, J. R., Draper, A. D., Pliszka, K., and Austin, M. E. (1991). Blueberries and cranberries (Vaccinium). Acta Hortic. 290, 393-458. doi: 10.17660/actahortic.1991.290.9

Lyrene, P. (1985). Effects of year and genotype on flowering and ripening dates in rabbiteye blueberry. HortScience 20, 407-409.

Lyrene, P. (1991). Fertile derivatives from sparkleberry $\times$ blueberry crosses. J. Am. Soc. Hortic. Sci. 116, 899-902.

Lyrene, P. (2006). Breeding southern highbush and rabbiteye blueberries. Acta Hortic. 715, 29-36. doi: 10.17660/actahortic.2006.715.1

Lyrene, P. M. (2002). Development of highbush blueberry cultivars adapted to Florida. J. Am. Pomol. Soc. 56, 79-85.

Lyrene, P. M., and Sherman, W. B. (2000). 'Star' southern highbush blueberry. HortScience 35, 956-957.

Madronich, S., McKenzie, R. L., Björn, L. O., and Caldwell, M. M. (1998). Changes in biologically active ultraviolet radiation reaching the Earth's surface. J. Photochem. Photobiol B Biol. 46, 5-19. doi: 10.1016/S1011-1344(98) 00182-1

Mainland, C. M. (1989). "Harvesting, sorting and packing quality blueberries," in 23rd Annual Open House, Southeastern Blueberry Council, North Carolina Univ.

Mainland, C. M., Buchanan, D. W., and Bartholic, J. F. (1977). The effects of five chilling regimes on bud break of highbush (Vacciniun corymbosum L.) and rabbiteye ( $V$. ashei Reade) blueberry hardwood cuttings. HortScience 12, 411.

Maqbool, R., Percival, D. C., Adl, M. S., Zaman, Q. U., and Buszard, D. (2012). In situ estimation of foliar nitrogen in wild blueberry using reflectance spectra. Can. J. Plant Sci. 92, 1155-1161. doi: 10.4141/cjps2011-203

McKenzie, R. L., Aucamp, P. J., Bais, A. F., Björn, L. O., Ilyas, M., and Madronich, S. (2011). Ozone depletion and climate change: impacts on UV radiation. Photochem. Photobiol. Sci. 10, 182-198. doi: 10.1039/c0pp90034f

Meza, F. J., Wilks, D. S., Riha, S. J., and Stedinger, J. R. (2003). Value of perfect forecasts of sea surface temperature anomalies for selected rain-fed agricultural locations of Chile. Agric. Forest Meteorol. 116, 117-135. doi: 10.1016/S01681923(03)00004-2

Mingeau, M., Perrier, C., and Améglio, T. (2001). Evidence of drought-sensitive periods from flowering to maturity on highbush blueberry. Sci. Hortic. 89, 23-40. doi: 10.1016/S0304-4238(00)00217-X

Moon, J. W. Jr., Flore, J. A., and Hancock, J. F. Jr. (1987a). A comparison of carbon and water vapor gas exchange characteristics between a diploid and highbush blueberry. J. Am. Soc. Hortic. Sci. 112, 134-138.

Moon, J. W. Jr., Hancock, J. F. Jr., Draper, A. D., and Flore, J. A. (1987b). Genotypic differences in the effect of temperature on $\mathrm{CO} 2$ assimilation and water use efficiency in blueberry. J. Am. Soc. Hortic. Sci. 112, 170-173.

Moretti, C. L., Mattos, L. M., Calbo, A. G., and Sargent, S. A. (2010). Climate changes and potential impacts on postharvest quality of fruit and vegetable crops: a review. Food Res. Int. 43, 1824-1832. doi: 10.1016/j.foodres.2009.10.013

Naik, D., Dhanaraj, A. L., Arora, R., and Rowland, L. J. (2007). Identification of genes associated with cold acclimation in blueberry (Vaccinium corymbosum L.) using a subtractive hybridization approach. Plant Sci. 173, 213-222. doi: 10.1016/j.plantsci.2007.05.003

NASA. (2015). NASA, NOAA Find 2014 Warmest Year in Modern Record (New York, NY)

NeSmith, D. S., Krewer, G., and Lindstrom, O. M. (1999). Fruit set of rabbiteye blueberry (Vaccinium ashei) after subfreezing temperatures. J. Am. Soc. Hortic. Sci. 124, 337-340.

Olmstead, J. W., Armenta, H. P. R., and Lyrene, P. M. (2013). Using sparkleberry as a genetic source for machine harvest traits for southern highbush blueberry. HortTechnology 23, 419-424.

Patten, K., Neuendorff, E. W., Nimr, G., Clark, J. R., and Fernandez, G. (1991). Cold injury of southern blueberries as a function of germplasm and season of flower bud development. HortScience 26, 18-20.
Peñuelas, J., Filella, I., and Gamon, J. A. (1995). Assessment of photosynthetic radiation-use efficiency with spectral reflectance. New Phytol. 131, 291-296.

Peñuelas, J., Filella, I., Biel, C., Serrano, L., and Savé, R. (1993). The reflectance at the $950-970 \mathrm{~nm}$ region as an indicator of plant water status. Int. J. Remote Sens. $14,1887-1905$

Percival, D. C., Sharpe, S., Maqbool, R., and Zaman, Q. (2012). Narrow band reflectance measurements can be used to estimate leaf area index, flower number, fruit set and berry yield of the wild blueberry (Vaccinium angustifolium Ait.). Acta Hortic. 926, 363-370. doi: 10.17660/actahortic.2012.926.51

Perkins-Veazie, P., Collins, J. K., and Howard, L. (2008). Blueberry fruit response to postharvest application of ultraviolet radiation. Postharvest Biol. Technol. 47, 280-285. doi: 10.1016/j.postharvbio.2007.08.002

Perrier, C., Mingeau, M., and Améglio, T. (2000). Effects of water stress on transpiration, radial growth and yield in highbush blueberry. Acta Hortic. 537, 923-928. doi: 10.17660/actahortic.2000.537.112

Peshlov, B. N., Dowelt, F. E., Drummond, F. A., and Donahue, D. W. (2009). Comparison of three near infrared spectrophotometers for infestation detection in wild blueberries using multivariate calibration models. J. Near Infrared. Spec. 17, 203-212. doi: 10.1255/jnirs.842

Ralph, P. J., and Gademann, R. (2005). Rapid light curves: a powerful tool to assess photosynthetic activity. Aquat. Bot. 82, 222-237. doi: 10.1016/j.aquabot.2005.02.006

Retamales, J. B., and Hancock, J. F. (2012). Blueberries. Wallingford, UK: CABI Publishing.

Retamales, J. B., Montecino, J. M., Lobos, G. A., and Rojas, L. A. (2008). Colored shading nets increase yields and profitability of highbush blueberries. Acta Hortic. 770, 193-197. doi: 10.17660/actahortic.2008.770.22

Rho, H., Yu, D. J., Kim, S. J., and Lee, H. J. (2012). Limitation factors for photosynthesis in 'Bluecrop' highbush blueberry (Vaccinium corymbosum) leaves in response to moderate water stress. J. Plant Biol. 55, 450-457. doi: 10.1007/s12374-012-0261-1

Rowland, L. J., and Levi, A. (1994). RAPD-based genetic linkage map of blueberry derived from a cross between diploid species (Vaccinium darrowi and $V$. elliottii). Theor. Appl. Genet. 87, 863-868. doi: 10.1007/BF00221139

Rowland, L. J., Bell, D. J., Alkharouf, N., Bassil, N. V., Drummond, F. A., Beers, L., et al. (2012). Generating genomic tools for blueberry improvement. IJFS 12, 276-287. doi: 10.1080/15538362.2011.619452

Rowland, L. J., Dhanaraj, A. L., Naik, D., Alkharouf, N., Matthews, B., and Arora, R. (2008). Study of cold tolerance in blueberry using EST libraries, cDNA microarrays, and subtractive hybridization. HortScience 43, 1975-1981.

Rowland, L. J., Ogden, E. L., and Ehlenfeldt, M. K. (2010). EST-PCR markers developed for highbush blueberry are also useful for genetic fingerprinting and relationship studies in rabbiteye blueberry. Sci. Hortic. 125, 779-784. doi: 10.1016/j.scienta.2010.05.008

Rowland, L. J., Ogden, E. L., Bassil, N., Buck, E. J., McCallum, S., Graham, J., et al. (2014). Construction of a genetic linkage map of an interspecific diploid blueberry population and identification of QTL for chilling requirement and cold hardiness. Mol. Breed. 34, 2033-2048. doi: 10.1007/s11032-0140161-9

Rowland, L. J., Ogden, E. L., Ehlenfeldt, M. K., and Vinyard, B. (2005). Cold hardiness, deacclimation kinetics, and bud development among 12 diverse blueberry genotypes under field conditions. J. Am. Soc. Hortic. Sci. 130, 508-514.

Rowland, L. J., Ogden, E. L., Takeda, F., Glenn, D. M., Ehlenfeldt, M. K., and Vinyard, B. T. (2013). Variation among highbush blueberry cultivars for frost tolerance of open flowers. HortScience 48, 692-695.

Rowland, L. J., Panta, G. R., Mehra, S., and Parmentier-Line, C. (2004). Molecular genetic and physiological analysis of the cold-responsive dehydrins of blueberry. J. Crop Improv. 10, 53-76. doi: 10.1300/J411v10n01_05

Rozema, J., van de Staaij, J., Björn, L. O., and Caldwell, M. M. (1997). UV-B as an environmental factor in plant life: stress and regulation. Trends Ecol. Evol. 12, 22-28. doi: 10.1016/S0169-5347(96)10062-8

Ruhland, C. T., Xiong, F. S., Clark, W. D., and Day, T. A. (2005). The influence of ultraviolet- $B$ radiation on growth, hydroxycinnamic acids and flavonoids of Deschampsia antarctica during Springtime ozone depletion in Antarctica. Photochem. Photobiol. 81, 1086-1093. doi: 10.1562/2004-09-18-RA-321

Santibañez, F., and Santibañez, P. (2007). Cambio climático y degradación de tierras en Lationoamerica y Chile. Ambiente Desarrollo 3, 54-63. 
Santibañez, F., and Santibañez, P. (2008). "Efectos del cambio climático en la agricultura," in IV Jornadas de Actualización en Riego y Fertirriego, Facultad de Ciencias Agrarias - U. N. Cuyo.

Semerdjieva, S. I., Phoenix, G. K., Hares, D., Gwynn-Jones, D., Callaghan, T. V., and Sheffield, E. (2003a). Surface morphology, leaf and cuticle thickness of four dwarf shrubs from a sub-Arctic heath following long-term exposure to enhanced levels of UV-B. Physiol. Plant. 117, 289-294. doi: 10.1034/j.13993054.2003.00006.x

Semerdjieva, S. I., Sheffield, E., Phoenix, G. K., Gwynn-Jones, D., Callaghan, T. V., and Johnson, G. N. (2003b). Contrasting strategies for UV-B screening in sub-Arctic dwarf shrubs. Plant Cell Environ. 26, 957-964. doi: 10.1046/j.13653040.2003.01029.x

Sims, D. A., and Gamon, J. A. (2003). Estimation of vegetation water content and photosynthetic tissue area from spectral reflectance: a comparison of indices based on liquid water and chlorophyll absorption features. Remote Sens. Environ. 84, 526-537. doi: 10.1016/S0034-4257(02)00151-7

Sinelli, N., Casiraghi, E., Barzaghi, S., Brambilla, A., and Giovanelli, G. (2011). Near infrared (NIR) spectroscopy as a tool for monitoring blueberry osmo-air dehydration process. Food Res. Int. 44, 1427-1433. doi: 10.1016/j.foodres.2011.02.046

Sinelli, N., Spinardi, A., Di Egidio, V., Mignani, I., and Casiraghi, E. (2008). Evaluation of quality and nutraceutical content of blueberries (Vaccinium corymbosum L.) by near and mid-infrared spectroscopy. Postharvest Biol. Technol. 50, 31-36. doi: 10.1016/j.postharvbio.2008.03.013

Spiers, J. M. (1976). Chilling regimens affect bud break in 'Tifblue' rabbiteye blueberry. J. Am. Soc. Hortic. Sci. 101, 84-86.

Sugiyama, T., Sugiyama, J., Tsuta, M., Fujita, K., Shibata, M., Kokawa, M., et al. (2010). NIR spectral imaging with discriminant analysis for detecting foreign materials among blueberries. J. Food Eng. 101, 244-252. doi: 10.1016/j.jfoodeng.2010.06.026

Tanner, C. B. (1963). Plant temperatures. Agron. J. 55, 210-211. doi: 10.2134/agronj1963.00021962005500020043x

Trehane, J. (2004). Blueberries, Blueberries and Other Vacciniums. Portland, OR: Timber Press.

Tsuta, M., Takao, T., Sugiyama, J., Wada, Y., and Sagara, Y. (2006). Foreign substance detection in blueberry fruits by spectral imaging. Food Sci. Technol. Res. 12, 96-100. doi: 10.3136/fstr.12.96
Tucker, C. J., and Sellers, P. J. (1986). Satellite remote sensing of primary production. Int. J. Remote Sens. 7, 1395-1416. doi: 10.1080/014311686089 48944

United Nations. (2010). Economics of Climate Change in Latin America and the Caribbean. Summary 2010. Santiago: United Nations.

Wei, H., Dhanaraj, A. L., Rowland, L. J., Fu, Y., Krebs, S. L., and Arora, R. (2005). Comparative analysis of expressed sequence tags from cold-acclimated and non-acclimated leaves of Rhododendron catawbiense Michx. Planta 221, 406-416. doi: 10.1007/s00425-004-1440-1

White, J. W., Andrade-Sanchez, P., Gore, M. A., Bronson, K. F., Coffelt, T. A., and Conley, M. M., Wang, G. (2012). Field-based phenomics for plant genetics research. Field Crops Res. 133, 101-112. doi: 10.1016/j.fcr.2012.04.003

WMO. (2011). Scientific Assessment of Ozone Depletion: 2010, Global Ozone Research and Monitoring Project-Report No. 52. World Metereological Organization. Geneva.

Yáñez, P., Retamales, J. B., Lobos, G. A., and del Pozo, A. (2009). Light environment within mature rabbiteye blueberry canopies influences flower bud formation. Acta Hortic. 810, 417-473. doi: 10.17660/ActaHortic.2009.810.61

Yang, C., and Lee, W. S. (2011). "Spectral signatures of blueberry fruits and leaves," in American Society of Agricultural and Biological Engineers Annual International Meeting 2011, ASABE 2011 (Louisville, KY).

Yang, C., Lee, W. S., and Gader, P. (2014). Hyperspectral band selection for detecting different blueberry fruit maturity stages. Comput. Electron. Agric. 109, 23-31. doi: 10.1016/j.compag.2014.08.009

Yang, C., Lee, W. S., and Williamson, J. G. (2012) Classification of blueberry fruit and leaves based on spectral signatures. Biosys Eng. 113, 351-362.

Conflict of Interest Statement: The authors declare that the research was conducted in the absence of any commercial or financial relationships that could be construed as a potential conflict of interest.

Copyright (c) 2015 Lobos and Hancock. This is an open-access article distributed under the terms of the Creative Commons Attribution License (CC BY). The use, distribution or reproduction in other forums is permitted, provided the original author(s) or licensor are credited and that the original publication in this journal is cited, in accordance with accepted academic practice. No use, distribution or reproduction is permitted which does not comply with these terms. 